\title{
Kemampuan Mahasiswa Program Studi Pendidikan Matematika STKIP Muhammadiyah OKU Timur Dalam Menyelesaikan Soal PS-TRE PIAAC
}

\author{
Hendra Lesmana ${ }^{1 *}$, Liana Septy ${ }^{2}$ \\ STKIP Muhammadiyah OKU Timur ${ }^{1}$, \\ UIN Raden Fatah Palembang ${ }^{2}$ \\ $\underline{\text { hendralesmana1302@gmail.com }}{ }^{1}, \underline{\text { lianasepti_uin@ }}$ radenfatah.ac.id $^{2}$ \\ *penulis korespondensi
}

\begin{tabular}{l}
\hline Informasi Artikel \\
\hline Revisi: \\
20 Agustus 2021 \\
Diterima: \\
23 Agustus 2021 \\
\\
Diterbitkan: \\
31 Agustus 2021 \\
\hline Kata Kunci \\
Kemampuan mahassiswa \\
Soal PIAAC \\
PS-TRE \\
ICT \\
Lingkungan kaya tekonologi
\end{tabular}

\begin{abstract}
Abstrak
Penilaian kemampuan anak usia 15 tahun secara global sudah dilakukan melalui PISA. Pembelajaran guna meningkatkan kemampuan yang diujikan PISA sudah sering dilakukan lebih dari satu dekade yang lalu. Hasil dari upaya-upaya tersebut tidak saja terlihat setelah mereka berusia di atas 15 tahun tetapi juga setelah mereka dewasa. Penilaian untuk mereka yang telah dewasa dilakukan melalui Programme for the International Assessment of Adult Competencies (PIAAC). Penelitian ini bertujuan untuk mendeskripsikan kemampuan orang-orang dewasa dalam menyelesaikan masalah yang berhubungan dengan lingkungan kaya teknologi. Peneliti memberikan soal-soal kepada mahasiswa semester 2 Program Studi Pendidikan Matematika STKIP Muhammadiyah OKU Timur yang berjumlah 16 orang. Soal-soal yang diberikan menuntut penggunaan kemampuan kemampuan mengakses, menginterpretasikan, dan menganalisis informasi yang ditemukan, mentransformasikan dan mengomunikasikan di dalam lingkungan digital. Penelitian ini merupakan penelitian campuran deskriptif dan kualitatif. Peneliti mengumpulkan lembar jawaban mahasiswa dalam bentuk file yang dikirim melalui aplikasi Whatsapp. Peneliti menganalisis hasil kerja mahasiswa dan membandingkan dengan beberapa alternatif solusi pada soal tersebut. Diperoleh hasil yaitu 1 mahasiswa menjawab menggunakan ICT, 5 mahasiswa yang menjawab tidak menggunakan ICT, 3 mahasiswa menjawab tidak tepat dan sisanya tidak menjawab.
\end{abstract}

\begin{abstract}
A global assessment of the ability of 15 year olds has been carried out through PISA. Learning to improve the abilities tested by PISA has often been carried out more than a decade ago. The results of these efforts are not only seen after they are over 15 years old but also after they grows up. Assessment for adults is done through the Programme for the International Assessment of Adult Competencies (PIAAC). This study aims to describe the ability of adults to solve problems related to technology-rich environments. The researcher gave questions to the second semester students of the Mathematics Education Study Program of STKIP Muhammadiyah OKU Timur, totaling 16 people. The questions given require the use of the ability to access, interpret, and analyze the information found, transformed and communicated in a digital environment. This research is a mixed descriptive and qualitative research. The researcher collected student answer sheets in the form of files sent via the Whatsapp application. The researcher analyzed the students' work and compared it with several alternative solutions to the problem. The results obtained were 1 student who answered using ICT in, 5 students who answer without ICT, 3 students answered uncorrectly and others did not answer.
\end{abstract}


Lesmana, H. \& Spty, L.

\section{Pendahuluan}

Pembelajaran yang berorientasi pada PISA telah dilakukan lebih dari satu dekade yang lalu. Keikutsertaan Indonesia pada PISA pun tidak dapat dibilang baru karena sudah sejak tahun 2000 Indonesia menjadi negara peserta PISA (Pratiwi, 2019, 52). Akan tetapi, walaupun terbilang sudah lama mengikuti PISA, Indonesia belum dapat menunjukkan perkembangan yang signifikan pada perolehan hasil PISA. Pada tahun 2018, Indonesia masih konsisten berada pada peringkat 10 besar terbawah dari seluruh negara peserta PISA (Shaleh, 2020, 30; Pratiwi, 2019, 52). Indonesia hanya menempati peringkat 74 dari 79 negara peserta PISA (OECD, 2021)

Sebenarnya telah sejak satu dekade lalu ditemukan celah antara isi kurikulum di Indonesia dengan soal yang diujikan di PISA (Zulkardi, 2010). Soal UN pun hanya berada di level rendah dan sedang level PISA (Kamaliyah dkk., 2013). Tetapi, upaya yang dilakukan hingga pada periode 2018 belum membuahkan hasil yang maksimal. Upaya yang telah dilakukan baik berupa pembelajaran maupun kegiatan berkaitan dengan pengenalan soal tipe PISA dirasa belum dapat mengubah ranking Indonesia pada penialain PISA. Terakhir, Mendikbud Nadiem Makarim pada tahun 2020 juga merespon rendahnya daya saing siswa Indonesia pada penilaian PISA melalui kebijakan Merdeka Belajar dan berusaha meningkatkan mutu pendidikan baik pada tahap persiapan, proses pembelajaran maupun sistem evaluasi (Kemdikbud, 2020). Sistem evaluasi yang sebelum tahun 2021 dilaksanakan melalui UN dan UNBK, mulai tahun 2021 diganti dengan Asesmen Nasional (AN). AKM yang merupakan salah satu bagian AN difokuskan pada kemampuan literasi dan numerasi yang merupakan juga fokus penilaian PISA. Layak kita tunggu rilis hasil penilaian PISA 2021 dari OECD.

Hasil dari sistem pembelajaran di Indonesia satu dekade lalu yaitu periode tahun 2011-2020 dapat kita lihat bukan hanya dari ranking PISA tahun 2018, tetapi juga berdasarkan laporan hasil survey Program for the International Assessment of Adult Competencies (PIAAC) yang menunjukkan bahwa orang-orang dewasa di Indonesia sangat lemah dalam hal literasi, numerasi dan pemecahan masalah dalam lingkungan kaya teknologi (PS-TRE) (OECD, 2016). Orang dewasa di Indonesia kurang sering membaca, menulis, bekerja dengan matematika, memecahkan masalah dan menggunakan komputer dalam pekerjaan meraka (OECD, 2016). Sebanyak 7.229 orang dewasa berusia 16-65 tahun yang disurvey memperoleh hasil yang tergolong rendah yaitu hanya kurang dari $1 \%$ responden yang memiliki level 4 dan 5, 3,4\% berada pada level 3 dan sisanya berada level 1-2 atau di bawahnya pada aspek literasi. Pada aspek numerasi, hanya sekitar 1,4\% yang berada pada level 4 dan 5, 9,1\% pada level 3 dan sisanya pada level 1 atau di bawahnya (OECD, 2016). Tentu saja rendahnya skor PISA Indonesia tahun 2018 dan PIAAC tahun 2016 menegaskan adanya suatu kelemahan sistem pendidikan di Indonesia.

Produk dari sistem pembelajaran di Indonesia satu dekade lalu menentukan bagaimana kemampuan orang-orang dewasanya untuk menyelesaikan permasalahan. Perubahan kurikulum sejak beberapa dekade lalu yang selalu menekankan pada pemecahan masalah seharusnya cukup mengakrabkan orang-orang dewasa Indonesia untuk dapat menyelesaikan masalah dengan kemampuan terbaiknya. Orang-orang dewasa yang dimaksud adalah anak-anak yang telah melalui tahun-tahun penilaian PISA tahun 2018 atau sebelumnya.

Penelitian-penelitian tentang PISA telah banyak dilakukan bahkan sampai 3 tahun terakhir. Beberapa penelitian 3 tahun terakhir seperti yang dilakukan oleh Habibi \& Suparman, 2020; Shaleh, 2020; Pratiwi, 2019; Ridzkiyah \& Effendi, 2021; Saputri dkk., 2020. Akan tetapi, penelitian-penelitian tersebut hanya berhenti pada soal tipe PISA saja dan belum ada yang mengambil meneliti kemampuan orang-orang dewasa dalam memecahkan masalah dalam lingkungan kaya teknologi. Oleh karena itu, peneliti melakukan sebuah penelitian kepada 16 orang mahasiswa semester 2 STKIP Muhammadiyah OKU Timur. Penelitian ini bertujuan untuk mendeskripsikan kemampuan mahasiswa semester 2 STKIP Muhammadiyah OKU Timur tahun akademik 2020/2021 dalam menyelesaikan permasalahan yang diberikan. Peneliti memberikan soal yang berkaitan dengan pemecahan masalah yang melibatkan penggunaan lingkungan kaya teknologi atau dikenal Problem Solving-Technology Rich Environment (PS-TRE) yang merupakan salah satu fokus dalam PIAAC. 
Lesmana, H. \& Spty, L.

\section{Soal PIAAC dan PS-TRE}

Untuk mengetahui kemampuan orang-orang dewasa, OECD membuat sebuah survei yaitu Programme for the International Assessment of Adult Competencies (PIAAC) (OECD, 2016, 1). PIAAC menyediakan sebuah gambaran tentang kecakapan orang-orang dewasa pada kemampuan memproses informasi yaitu literasi (kemampuan untuk memahami dan merespon dengan tepat teks tertulis), numerasi (kemampuan untuk menggunakan konsep-konsep bilangan dan matematika), dan pemecahan masalah pada lingkungan kaya teknologi atau sering disebut PS-TRE (kemampuan mengakses, menginterpretasikan, dan menganalisis informasi yang ditemukan, mentransformasikan dan mengomunikasikan di dalam lingkungan digital) (OECD, 2016, 1).

Kecakapan berada pada skala 500 yang dibagi ke dalam level-level tersendiri yang tiap level menjelaskan apa yang dapat dilakukan oleh seseorang (OECD, 2016, 1). Enam kecakapan ditentukan untuk literasi dan numerasi yaitu level 1 sampai level 5 ditambah dengan satu level di bawah level 1 dan empat kecakapan ditentukan untuk PS-TRE yaitu level 1 sampai 3 ditambah 1 level di bawah level 1) (OECD, 2016, 1). PIAAC baru sekali diadakan di Indonesia yaitu di Indonesia pada tanggal 1 April 2014 sampai 31 Maret 2015 dengan responden sebanyak 7.229 orang dewas berusia 16-65.

Survei menunjukkan hasil yang tergolong rendah yaitu hanya kurang dari $1 \%$ responden yang memiliki level 4 dan 5, 3,4\% berada pada level 3 dan sisanya berada level 1-2 atau di bawahnya pada aspek literasi (OECD, 2016, 2). Pada aspek numerasi, hanya sekitar 1,4\% yang berada pada level 4 dan 5, $9,1 \%$ pada level 3 dan sisanya pada level 1 atau di bawahnya (OECD, 2016, 2). Sekitar 14.5\% pekerja di Jakarta diidentifikasi memiliki kemampuan lebih dari yang dibutuhkan pada pekerjaan mereka, $10.8 \%$ di atas rata-rata OECD (OECD, 2016, 7). Sekitar 4.7\% pekerja di Jakarta dapat dianggap kurang terampil/ kurang mahir dari kemampuan yang dibutuhkan pada pekerjaannya, 3,8\% mendekati rata-rata OECD (OECD, 2016, 7). Keterampilan pemrosesan informasi yang digunakan di tempat kerja digambarkan seperti pada Gambar 1 berikut.

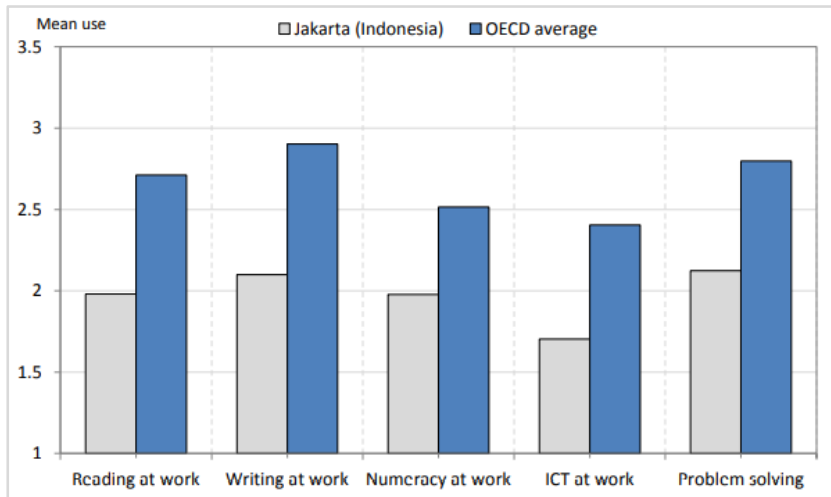

Gambar 1. Keterampilan Pemrosesan Informasi Yang Digunakan Di Tempat Kerja

Sumber: OECD $(2016,7)$

\section{Penggunaan ICT}

Secara sederhana, menurut Freiman (Clark-Wilson dkk., 2020, 1225), teknologi dapat diartikan sebagai perangkat keras yang nyata (misal komputer, kalkulator, handytalk, telepon genggam, smartphones dan lain sebagainya) yang dilengkapi software yang menawarkan interaksi antara perangkat dan penggunanya. Menurut Sinclair \& Robutti (Clark-Wilson dkk., 2020, 1225), penggunaan teknologi digital memiliki dua fungsi utama yaitu (a) untuk membantu pengelolaan pekerjaan guru seperti menghasilkan lembar kegiatan siswa dan (b) sebagai cara baru untuk melakukan matematika dan menggambarkan matematika. Mendekati akhir abad yang lalu, kegunaan teknologi bagi pendidik matematika berubah menjadi 3 fungsi yaitu sebagai penghubung, mengatur komunitas, berkomunikasi, dan berbagi materi, mengatur keuangan dan industri, yang sudah membantu mahasiwa untuk secara mandiri bekerja yang berfokus pada praktek dan penilaian pengetahuan dan kemampuan matematika. 
Lesmana, H. \& Spty, L.

Traglová, dkk. telah mendokumentasikan dan mengevaluasi penelitian matematika dalam 20 tahun terakhir yang berfokus pada dampak teknologi digital pada kegiatan belajar dan mengajar matematika dan menemukan bahwa dua hal penting adalah tugas dan kerangka teori (Günster \& Weigand, 2020, 1260). Tugas disusun menggunakan teknologi digital berdasarkan kerangka teori.

Di Indonesia, terdapat istilah baru untuk menyebut ICT yaitu kecerdasan buatan. Pada masa sekarang, kecerdasan buatan semacam itu berkembang dengan sangat cepat dan menawarkan kemudahan dalam penggunaan maupun untuk terhubung satu dengan lainnya (Clark-Wilson dkk., 2020, 1225). Pada periode 2010 hingga 2015, (Stacey, 2015, 11), menyatakan bahwa ada beberapa alasan penggunaan komputer yaitu pertama, komputer sudah biasa digunakan di tempat kerja dan di kehidupan sehari-hari di abad 21 yang pada level kompetensi literasi matematika telah banyak memasukkan aktivitas yang menggunakan komputer. Kedua, komputer untuk menulis soal-soal tes yang interaktif, asli dan menarik, dan dapat menjadi alat pembeda kemampuan siswa. Günster \& Weigand, (2020), juga berhasil mendesain sebuah tugas menggunakan teknologi digital yang dikenal dengan FOM.

\section{Metode}

Penelitian ini termasuk ke dalam penelitian campuran deskriptif dan metode kualitatif yang kadang saling menggantikan karena keduanya menggunakan data yang naturalistik atau wajar, sebagaimana adanya, dan tanpa manipulasi (Nassaji, 2015, 129). Nassaji $(2015,129)$, mengatakan bahwa metode penelitian deskriptif bertujuan untuk mendeskripsikan sebuah fenomena, dan karakteristiknya yang menitik beratkan pada bagaimana atau mengapa sesuatu terjadi.

Subjek penelitian ini adalah 16 orang mahasiswa semester 2 Program Studi Pendidikan Matematika STKIP Muhammadiyah OKU Timur yang beralamat di Jln. KH. Ahmad Dahlan Desa Harjowinangun BK $10 \mathrm{Kec}$. Belitang Kab. OKU Timur Provinsi Sumatera Selatan. Menurut Sugiyono (2013, 82), teknik dokumentasi merupakan catatan peristiwa yang telah berlalu, yang biasanya berbentuk tulisan, gambar, atau karya monumental dari seseorang. Pada masa Covid-19, peneliti memberikan soal melalui pesan di aplikasi Whatsapp pada 27 Juli 2021. Mahasiswa selesai mengumpulkan jawaban mereka pada 03 Agustus tahun 2021. Data yang terkumpul file-file foto maupun berkas berbentuk pdf yang berisi jawaban-jawaban mahasiswa.

Data yang sudah dikumpulkan dianalisis dengan cara membandingkannya dengan beberapa alternatif solusi pada tiap soal. Data yang sudah dianalisis kemudian disajikan dalam bentuk paragraf deskripsi dilengkapi tabel, diagram, ataupun grafik.

\section{Hasil dan Pembahasan Hasil Penelitian}

Peneliti berhasil mengumpulkan 9 jawaban dari 16 orang mahasiswa yang menjadi subjek penelitian. Penelitia memberikan 5 soal yang menuntut penyelesaian masalah menggunakan teknologi. Mahasiswa diminta untuk menjawab soal dengan memberikan jawaban dari tiap permasalahan yang ditanyakan; mendeskripsikan cara menyelesaikan permasalahan; mendeskripsikan cara menggunakan daya upaya/ potensi dan atau peralatan yang dimiliki.

Pada soal nomor 1, dari 9 orang yang mengumpulkan jawaban tentang banyaknya jembatan permanen yang dapat dilalui mobil angkutan ayng melintasi jalan sepanjang rute Campang Tiga hingga Kantor Bupati OKU Timur, terdapat 2 jawaban milik IM (a) dan Skh (b) yang dalam pengerjaannya menggunakan ICT. IM menampilkan potongan pencarian banyak jembatan di sepanjang rute Campang Tiga hingga Kantor Bupati OKU Timur dengan menggunakan tampilan citra Satelit di Google Map. Sedangkan, Skh hanya menggunakan Google Map untuk mengetahui rutenya, tetapi Skh salah dalam menyimpulkan banyaknya jembatan. Jawaban 7 mahasiswa lain berisi perhitungan angka untuk menjawab banyaknya jembatan tanpa berusaha menggunakan teknologi yang dimilikinya seperti smartphone. Potongan jawaban IM dan Skh dapat dilihat pada Gambar 2. 
Lesmana, H. \& Spty, L.

Jawab: berdasarkan data di google maps, di sepanjang rute antara Campang Tiga Kecamatan Cempaka - Kantor Bupati OKU Timur terdapat kurang lebih 16 jembatan permanen yang dapat dilalui oleh mobil angkutan

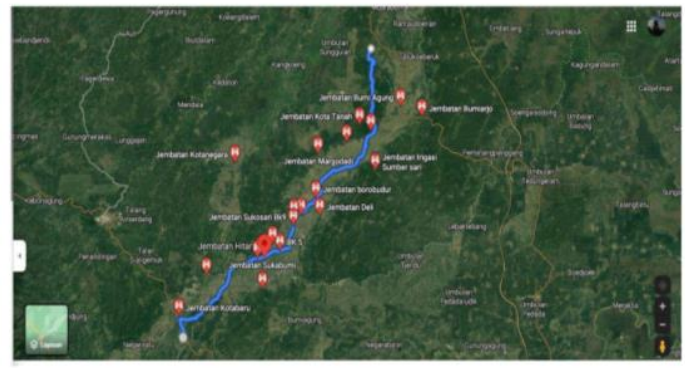

(a)

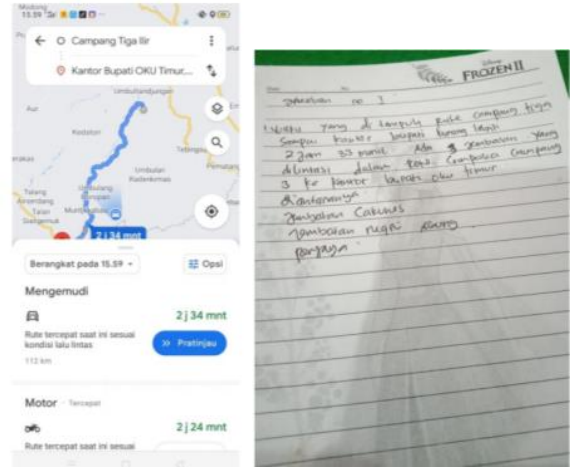

(b)

Gambar 2. Potongan Jawaban Mahasiswa pada Soal Nomor 1

Pada soal nomor 2, dari 9 orang yang mengumpulkan jawaban tentang estimasi lamanya beras hasil panen tahun 2021 di kecamatan Belitang habis dikonsumsi oleh warga Kecamatan Belitang, terdapat 1 jawaban yaitu milik IM (a) yang diperkirakan menggunakan data berasal dari laman Badan Pusat Statistik OKU Timur. Akan tetapi, pada penarikan kesimpulan tidak diketahui dari mana diperoleh jawaban 6-8 tahun. Padahal apabila IM mau mencari informasi dari internet tentang kebutuhan beras dalam satu kali makan seperti misal pada https://lokadata.id/artikel/berapa-konsumsiberas-kita-setahun, IM dapat menjawab permasalahan ini dengan hasil yang lebih presisi. Sedangkan, jawaban KR menjawab permasalahan tersebut dengan membuat estimasi kebutuhan beras dalam satu kali makan tanpa melihat informasi dari internet dan tidak menghasilkan jawaban yang presisi. Potongan jawaban dari IM dan KR dapat dilihat pada Gambar 3.

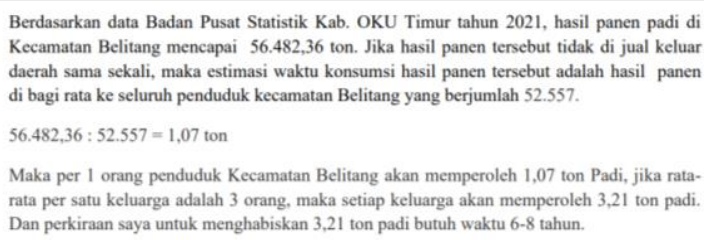

Berdasarkan data Badan Pusat Statistik Kab. OKU Timur tahun 2021, hasil panen padi di Kecamatan Belitang mencapai $56.482,36$ ton. Jika hasil panen tersebut tidak di jual kelue daerah sama sekali, maka estimasi waktu konsumsi hasil panen tersebut adalah hasil panen di bagi rata ke seluruh penduduk kecamatan Belitang yang berjumlah 52.557 .

$56.482,36: 52.557=1,07$ ton

Maka per 1 orang penduduk Kecamatan Belitang akan memperoleh 1,07 ton Padi, jika ratarata per satu keluarga adalah 3 orang, maka setiap keluarga akan memperoleh 3,21 ton padi. Dan perkiraan saya untuk menghabiskan 3,21 ton padi butuh waktu 6-8 tahun.

(a)

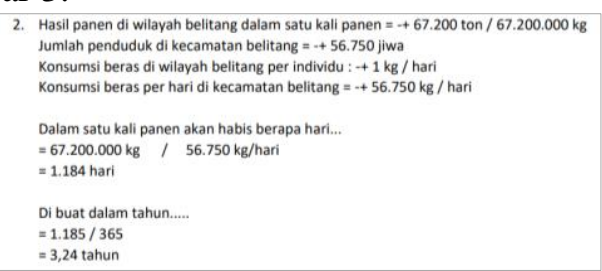

(b)

Gambar 3. Potongan Jawaban Mahasiswa pada Soal Nomor 2

Pada soal nomor 3, dari 9 orang yang mengumpulkan jawaban tentang rute terdekat yang selisihnya tidak lebih dari $20 \mathrm{~km}$ menggunakan mobil dari Gumawang BK 10 hingga Benteng Kuto Besak Palembang, terdapat 2 jawaban yaitu milik IM (a) dan SRM (b) yang menjawab menggunakan data dari Google Map dan 1 jawaban milik MVB yang menggunakan skrip seperti yang sering dibacakan oleh pemandu Google Map. IM menampilkan potongan pencarian rute Gumawang BK 10 Benteng Kuto Besak Palembang di Google Map. SRM menggunakan data Google Map tetapi salah menuliskan rute sehingga salah dalam menyimpulkan jawaban. MVB tidak memberikan kesimpulan jawaban yang diminta. Jawaban 6 mahasiswa lain berisi rute-rute tanpa diketahui dari mana mahasiswa tahu rute tersebut. Potongan jawaban IM, SRM, dan MVB dapat dilihat pada Gambar 4.

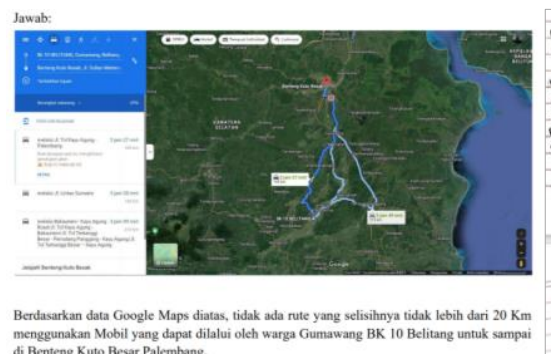

(a)

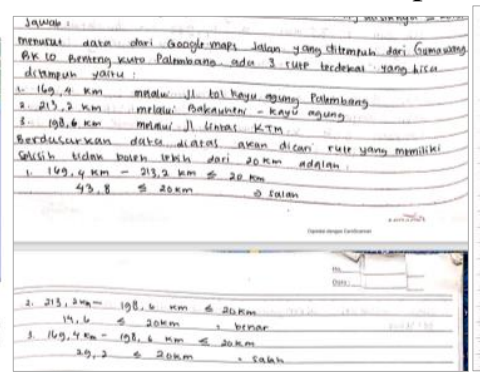

(b)

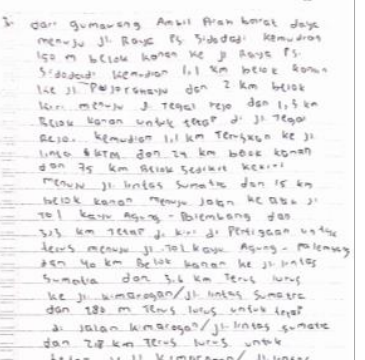

(c)

Gambar 4. Potongan Jawaban Mahasiswa pada Soal Nomor 3 
Lesmana, H. \& Spty, L.

Pada soal nomor 4, dari 9 orang yang mengumpulkan jawaban tentang jumlah barisan notasi faktorial, terdapat 4 jawaban yaitu milik SRM (a), DAP (b), ANA, dan RM yang menjawab dengan mencari nilai setiap bilangan. Akan tetapi, tidak ada jawaban yang secara tuntas menjawab hingga kesimpulan. Sedangkan 5 mahasiswa lain menggunakan rumus jumlah $\mathrm{n}$ suku pertama tetapi tetap saja mengalami kesalahan pada hasil akhir. Soal ini menuntut mahasiswa mampu untuk menggunakan aplikasi komputer yaitu Ms. Excel dalam penyelesaiannya soal. Perhitungan yang rumit tersebut menjadi cepat dan mudah dengan menggunakan Ms. Excel. Potongan jawaban IM, SRM, dan MVB dapat dilihat pada Gambar 5.

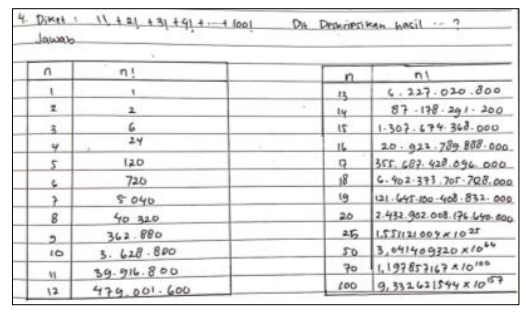

(a)

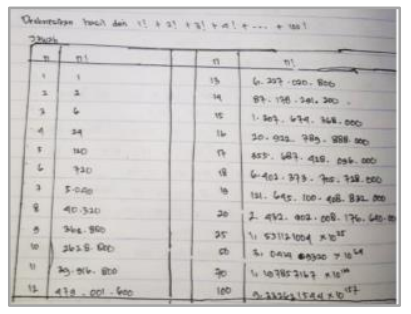

(b)

Gambar 5. Potongan Jawaban Mahasiswa pada Soal Nomor 4

Pada soal nomor 5, dari 9 orang yang mengumpulkan jawaban tentang harga lemari berwarna, terdapat 2 jawaban yaitu milik IM (a) dan KR yang mencari harganya dengan cara membuka aplikasi belanja online. Sedangkan 7 mahasiswa lain menggunakan pengalaman dan adapula yang menebak saja. Potongan jawaban IM, SRM, dan MVB dapat dilihat pada Gambar 6.

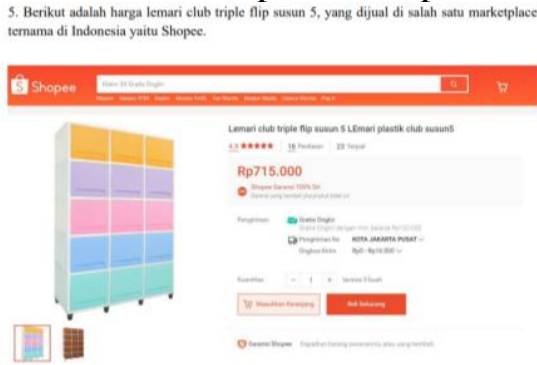

Gambar 6. Potongan Jawaban Mahasiswa pada Soal Nomor 5

\section{Pembahasan}

Dari hasil penelitian di atas terlihat bahwa mayoritas subjek penelitian tidak terbiasa mengerjakan masalah yang menuntut penggunaan ICT. Kondisi orang dewasa di Jakarta mirip dengan keadaan di Kecamatan Belitang yang terdapat gap antara pekerja yang berkemampuan tinggi dan orang dewasa yang berkemampuan kurang dari yang dibutuhkan (OECD, 2016, 7). Penggunaan teknologi yang secara sederhana oleh Clark-Wilson dkk. (2020, 1225) diartikan sebagai komputer, kalkulator, handytalk, telepon genggam, smartphones dan lain sebagainya merupakan sebuah kemampuan yang harus dimiliki oleh orang dewasa pada masa kini. Hasil penelitian ini juga menjelaskan bahwa kemampuan orang dewasa dalam menyelesaikan permasalahan yang menggunakan ICT juga seirama dengan nilai Indonesia pada penilaian PISA yang tahun 2018 menempatkan Indonesia pada peringkat 10 besar terbawah (Shaleh, 2020, 30; Pratiwi, 2019, 52) tepatnya peringkat 74 dari 79 negara peserta PISA (OECD, 2021). Perlu upaya untuk menguatkan kemampuan dalam menyelesaikan soal tipe PISA maupun PIAAC agar peringkat Indonesia dapat terdongkrak naik.

\section{Simpulan}

Berdasarkan hasil penelitian dan pembahasan dapat disimpulkan bahwa dari 16 orang mahasiswa, terdapat 1 mahasiswa menjawab menggunakan ICT, 5 mahasiswa yang menjawab tidak menggunakan ICT, 3 mahasiswa menjawab tidak tepat dan sisanya tidak menjawab. 


\section{Rekomendasi}

Berdasarkan simpulan, dapat direkomendasikan kepada peneliti lainnya untuk dapat melakukan penelitian tentang PIAAC pada aspek literasi, numerasi maupun PS-TRE yang hasilya dapat digunakan untuk memperbaiki pembelajaran di kelas. Selain itu, soal PIAAC dapat kolaborasikan dengan etnomatematika.

\section{Ucapan Terima Kasih}

Peneliti mengucapkan terima kasih banyak kepada pengelola Jurnal Ilmu Pendidikan Matematika MathEdu Universitas Timor, yang sudah bersedia untuk mempublikasi naskah ini.

\section{Referensi}

Clark-Wilson, A., Robutti, O., \& Thomas, M. (2020). Teaching with digital technology. ZDM, 52(7), 1223-1242. https://doi.org/10.1007/s11858-020-01196-0

Günster, S. M., \& Weigand, H.-G. (2020). Designing digital technology tasks for the development of functional thinking. ZDM, 52(7), 1259-1274. https://doi.org/10.1007/s11858-020-01179-1

Habibi, H., \& Suparman, S. (2020). Literasi Matematika dalam Menyambut PISA 2021 Berdasarkan Kecakapan Abad 21. JKPM (Jurnal Kajian Pendidikan Matematika), 6(1), 57. https://doi.org/10.30998/jkpm.v6i1.8177

Kamaliyah, K., Zulkardi, Z., \& Darmawijoyo, D. (2013). Developing the Sixth Level of PISA-Like Mathematics Problems for Secondary School Students. Journal on Mathematics Education, 4(1), 9-28. https://doi.org/10.22342/jme.4.1.559.9-28

Kemdikbud, K. (2020). Hasil pisa Indonesia 2018 akses makin meluas saatnya tingkatkan kualitas. diakses dari https://www.kemdikbud.go.id/main/blog/2019/12/hasil-pisa-indonesia-2018-aksesmakin-meluas-saatnya-tingkatkan-kualitas tanggal 01 Agustus 2021

La Hewi, \& Shaleh, Muh. (2020). Refleksi Hasil PISA (The Programme For International Student Assesment): Upaya Perbaikan Bertumpu Pada Pendidikan Anak Usia Dini). Jurnal Golden Age, 4(01). https://doi.org/10.29408/jga.v4i01.2018

Nassaji, H. (2015). Qualitative and descriptive research: Data type versus data analysis. Language Teaching Research, 19(2), 129-132. https://doi.org/10.1177/1362168815572747

OECD. (2016). Skills Matter: Further Results from the Survey of Adult Skills. OECD. https://doi.org/10.1787/9789264258051-en

OECD, O. (2021). Reading performance (PISA) (indicator) [Organisasi]. Reading Performance (PISA). https://data.oecd.org/pisa/reading-performance-pisa.htm

Pratiwi, I. (2019). Efek Program PISA Terhadap Kurikulum DI Indonesia. Jurnal Pendidikan dan Kebudayaan, 4(1), 51. https://doi.org/10.24832/jpnk.v4i1.1157

Ridzkiyah, N., \& Effendi, K. N. S. (2021). Analisis Kemampuan Literasi Matematis Siswa SMA dalam Menyelesaikan Soal Program Fotr International Student Assesment (PISA). JIPMat, 6(1), 1-13. https://doi.org/10.26877/jipmat.v6i1.8237

Saputri, N. W., Turidho, A., Zulkardi, Z., Darmawijoyo, D., \& Somakim, S. (2020). Desain Soal PISA Konten Uncertainty and data konteks penyebaran covid-19. EDU-MAT: Jurnal Pendidikan Matematika, 8(2). https://doi.org/10.20527/edumat.v8i2.8564

Stacey, K. (2015). The International Assessment of Mathematical Literacy: PISA 2012 Framework and Items. Dalam S. J. Cho (Ed.), Selected Regular Lectures from the 12th International Congress on Mathematical Education (hlm. 771-790). Springer International Publishing. https://doi.org/10.1007/978-3-319-17187-6_43

Sugiyono, S. (2013). Metode Penelitian Kuantitatif, Kualitatif dan R\&D. Alfabeta.

Zulkardi, Z. (2010). PISA, KTSP AND UN. Dalam Prosiding KNM XV (hlm. 53-54). IndoMS dan Jurusan Matematika UNIMA Manado. http://repository.unsri.ac.id/id/eprint/6327 